\title{
Peran Camat dalam Penertiban Pasar Liar di Desa Lalang Kecamatan Sunggal Kabupaten Deli Serdang
}

\author{
The Role of the Camat in Controlling Illegal Markets in \\ Lalang Village, Sunggal District, Deli Serdang Regency
}

\author{
Muhammad Nurdin, Adam \& Budi Hartono* \\ Program Studi Magister Ilmu Administrasi Publik, Universitas Medan Area, Indonesia
}

Diterima:10 Juni 2021; Disetujui: 15 Desember 2021; Dipublish: 01 Januari 2022

\begin{abstract}
Abstrak
Tanggungjawab penertiban pasar liar lalang berada di tangan Kecamatan Sunggal, dimana camat juga menarik retribusi dari para pedagang tersebut sesuai dengan peraturan camat. Tetapi dengan timbulnya berbagai masalah dari keberadaan pasar liar tersebut menjadi gambaran bahwa camat masih kurang berperan dalam melakukan pengelolaan pasar liar di daerahnya, sehingga menjadi sumber gangguan bagi pengguna jalan lainnya. Tujuan penelitian untuk mengetahui peran Camat dalam penertiban pasar liar di Desa Lalang Kecamatan Sunggal Kabupaten Deli Serdang. Manfaat penelitian untuk menambah wawasan dan pengetahuan di bidang penertiban pasar liar. Penelitian ini merupakan penelitian kualitatif dimana peneliti terjun langsung ke lapangan untuk meneliti obyek kajiannya dan mengadakan interaksi langsung dengan masyarakat. Pembahasan peran camat dalam penertiban pasar liar dalam penelitian ini didasarkan pada teori peran yang dikemukakan oleh Biddle dan Thomas, yaitu yang terdiri dari harapan, norma, wujud perilaku, serta penilaian dan sanksi. Camat memiliki peran penting dalam mengatur berbagai aktivitas yang dilakukan oleh masyarakat, termasuk juga pengaturan terhadap pasar agar keberadaan pasar tersebut tidak menimbulkan masalah bagi kelompok masyarakat lainnya.

Kata Kunci: Camat; Pasar; Penertiban
\end{abstract}

\begin{abstract}
The responsibility for controlling the weeds is in the hands of the Sunggal sub-district, where the sub-district also collects retribution from the traders in accordance with the sub-district regulations. However, with the emergence of various problems from the existence of the illegal market, it becomes an illustration that the sub-district head is still not playing a role in managing the illegal market in his area, thus becoming a source of disturbance for other road users. The purpose of the study was to determine the role of the Camat in controlling the illegal market in Lalang Village, Sunggal District, Deli Serdang Regency. The benefits of research to add insight and knowledge in the field of controlling illegal markets. This research is a qualitative research in which researchers go directly to the field to examine the object of study and conduct direct interaction with the community. The discussion on the role of the subdistrict head in controlling illegal markets in this study is based on the role theory proposed by Biddle and Thomas, which consists of expectations, norms, forms of behavior, as well as assessments and sanctions. The Camat has an important role in regulating various activities carried out by the community, including regulating the market so that the existence of the market does not cause problems for other community groups.

Keywords: Camat; Market; Order
\end{abstract}

How to Cite: Nurdin, M., Adam., \& Hartono, B. (2022). Peran Camat dalam Penertiban Pasar Liar di Desa Lalang Kecamatan Subggal Kabupaten Deli Serdang. PERSPEKTIF, 11 (1): 187-194

*Corresponding author:

E-mail:adam@staff.uma.ac.id ISSN 2085-0328 (Print) ISSN 2541-5913 (online) 


\section{PENDAHULUAN}

Salah satu upaya pemerintah dalam rangka memberdayakan pedesaan adalah dengan mengelola pasar agar dapat memberikan manfaat yang sebesar-besarnya dalam transaksi perdagangan di pedesaan. Transaksi perdagangan pedesaan tentu sangat tergantung pada pasar karena sebagian besar masyarakat desa memasarkan hasil-hasil produksinya, khususnya produk pertanian ke pasar yang sering juga disebut dengan istilah pajak. Peran pasar di pedesaan semakin penting karena pasar merupakan satu-satunya tempat dimana masyarakat desa dapat menjual hasil produksinya serta membeli bahan-bahan kebutuhan yang penting dalam pemenuhan kebutuhan hidup sehari-hari.

Secara definisi, pasar adalah sebagai tempat bertemunya pembeli dan penjual untuk melakukan transaksi jual-beli barang dan jasa. Pasar merupakan salah satu dari berbagai sistem hubungan sosial dan infrastruktur di mana masyarakat atau pelaku usaha menjual barang dan jasa untuk orang-orang dengan mengharapkan keuntungan. Jadi jelas bahwa pasar diperlukan untuk menjual hasil usaha masyarakat agar dapat memperoleh keuntungan, sehingga dapat dikatakan bahwa inti dari transaksi pasar adalah memperoleh keuntungan atau laba, dimana keuntungan tersebut akan digunakan masyarakat untuk tetap eksis menjalani kehidupan. Tanpa adanya keuntungan yang diperoleh dari pasar, tentu masyarakat desa tidak akan bertahan eksis dan mengembangkan diri. Sedemikian pentingnya peran pasar dalam kehidupan manusia sehingga pemerintah selalu berupaya agar terdapat pasar yang kondusif bagi aktivitas ekonomi masyarakat (Suharyanto et al., 2020; Sarimah et al, 2016),

Secara definisi, pasar adalah sebagai tempat bertemunya pembeli dan penjual untuk melakukan transaksi jual-beli barang dan jasa. Pasar merupakan salah satu dari berbagai sistem hubungan sosial dan infrastruktur di mana masyarakat atau pelaku usaha menjual barang dan jasa untuk orang-orang dengan mengharapkan keuntungan (Suharyanto et al., 2020). Jadi jelas bahwa pasar diperlukan untuk menjual hasil usaha masyarakat agar dapat memperoleh keuntungan, sehingga dapat dikatakan bahwa inti dari transaksi pasar adalah memperoleh keuntungan atau laba, dimana keuntungan tersebut akan digunakan masyarakat untuk tetap eksis menjalani kehidupan. Tanpa adanya keuntungan yang diperoleh dari pasar, tentu masyarakat desa tidak akan bertahan eksis dan mengembangkan diri. Sedemikian pentingnya peran pasar dalam kehidupan manusia sehingga pemerintah selalu berupaya agar terdapat pasar yang kondusif bagi aktivitas ekonomi masyarakat.

Salah satu pasar liar yang juga sering menimbulkan kemacetan adalah pasar liar yang terdapat di Desa Lalang Kecamatan Sunggal Kabupaten Deli Serdang. Pasar liar di desa lalang tersebut sering menimbulkan kemacetan terlebih karena berada di persimpangan jalan nasional yang banyak dilalui oleh kenderaan, baik kenderaan dalam kota maupun kenderaan antar kota dan antar provinsi. Permasalahan semakin besar karena jam operasional pasar tumpah tersebut hampir sama dengan jam operasional pasar tradisional, sehingga kemacetan dapat terjadi setiap saat.

Sebenarnya, terkait pasar liar ini muspika setempat telah berupaya menertibkannya, sehingga terdapat kesepakatan antara pedagang, muspika dan kelapa desa yang intinya adalah bahwa para pedagang hanya dapat diizinkan membuka lapak di trotoar dan bahu jalan pada jam 00.00 sampai jam 06.30. Tujuannya agar tidak menjadi sumber kemacetan. Namun karena tidak adanya pengawasan melekat maka kesepakatan tersebut kemudian dilanggar para pedagang sehingga kemacetan kembali terjadi.

Tanggungjawab penertiban pasar liar lalang berada di tangan Kecamatan Sunggal, dimana camat juga menarik retribusi dari para pedagang tersebut sesuai dengan peraturan camat. Tetapi dengan timbulnya berbagai masalah dari keberadaan pasar liar tersebut menjadi gambaran bahwa camat masih kurang berperan dalam melakukan pengelolaan pasar liar di daerahnya, sehingga menjadi sumber gangguan bagi pengguna jalan lainnya. Oleh karena itu penulis tertarik melakukan penelitian dengan judul: Peran Camat Dalam Penertiban Pasar Liar di Desa Lalang Kecamatan Sunggal Kabupaten Deli Serdang.

\section{METODE PENELITIAN}

Metode penelitian dalam hal ini berfungsi untuk menjawab permasalahan yang diangkat dalam penelitian. Guna menjawab dan mencari pemecahan permasalahan maka penelitian ini akan menggunakan metode-penelitian 
kualitatif Pendekatan kualitatif ini, peneliti akan terjun langsung ke lapangan untuk meneliti obyek kajiannya dan mengadakan interaksi langsung dengan masyarakat yang bertujuan mendapatkan informasi yang mendalam mengenai Peran Kepala Desa Dalam Pengelolaan Pasar Tumpah di Desa Lalang Kecamatan Sunggal Kabupaten Deli Serdang. Penelitian ini menggunakan pendekatan kualitatif untuk menghasilkan data deskriptif berupa kata-kata tertulis atau lisan dari orangorang dan perilaku yang dapat diamati (Bogdan dan Taylor dalam Moleong, 2010). Teknik pengumpulan data yang dilakukan dalam penelitian ini adalah dengan wawancara dan observasi. Teknik analisis data yang digunakan dalam penelitian ini adalah analisis data kualitatif deskriptif, yaitu data yang terkumpul dianalisa dengan menguraikan serta mengaitkan dengan teori-teori yang sesuai dengan permasalahan yang ada, kemudian akan memberikan interprestasi terhadap hasil yang relevan dan kemudian diambil kesimpulan dan saran. Dalam penelitian ini kegiatan analisis data dilakukan dengan cara mengelompokan data yang diperoleh dari sumber data terkait dengan Peran Kepala Desa Dalam Pengelolaan Pasar Tumpah.

\section{HASIL DAN PEMBAHASAN Pasar}

Pasar merupakan akibat/hasil dari pola kegiatan manusia yang terjadi karena adanya saling membutuhkan, sehingga terjadi pola pertukaran antara barang dan jasa. Kompleksitas kebutuhan akan mengakibatkan kompleksitas jumlah orang, jenis barang, cara pertukaran dan membutuhkan tempat yang semakin luas (Kotler dan Amstrong, 2014). Ginanjar (2012) menyatakan bahwa pasar adalah tempat untuk menjual dan memasarkan barang atau sebagai bentuk penampungan aktivitas perdagangan. Pasar pada mulanya merupakan perputaran dan pertemuan antara persediaan dan penawaran barang dan jasa. Definisi pasar liar tidak dapat ditemukan dalam peraturan perundangan sehingga secara implisit dapat dinyatakan bahwa pemerintah belum menganggap perlu pengawasan dan pengelolaan jenis pasar tersebut. Sementara itu menurut Kamus Besar Bahasa Indonesia, pasar tumpah adalah pasar sesaat yang terjadi ketika terdapat sebuah keramaian atau perayaan. Namun bagi masyarakat, sebutan pasar liar adalah salah satu jenis pasar tradisional dengan kegiatan pasar yang sifatnya sementara dengan wadah berjualan yang tersedia tidak permanen atau semi permanen dan aktivitasnya hanya untuk waktu-waktu tertentu dimana setiap harinya berlangsung hanya beberapa jam saja, baik pada pagi hari ataupun sore hari. Membahas pasar liar terkait dengan Market Area.

Blair (2015) mengungkapkan bahwa Market area adalah suatu wilayah yang diperkirakan di mana suatu produk bisa dijual. Outer limit terbagi dalam dua jenis, yaitu ideal outer range dan real outer range. Ideal outer range adalah jarak maksimum yang akan ditempuh oleh konsumen untuk memperoleh barang kebutuhannya selama biaya transportasi ditambah harga barang yang dibelinya masih dipandang lebih murah daripada harga rata-rata.

Salah satu pasar liar yang juga sering menimbulkan kemacetan adalah pasar liar yang terdapat di Desa Lalang Kecamatan Sunggal Kabupaten Deli Serdang. Pasar liar di desa lalang tersebut sering menimbulkan kemacetan terlebih karena berada di persimpangan jalan nasional yang banyak dilalui oleh kenderaan, baik kenderaan dalam kota maupun kenderaan antar kota dan antar provinsi. Permasalahan semakin besar karena jam operasional pasar tumpah tersebut hampir sama dengan jam operasional pasar tradisional, sehingga kemacetan dapat terjadi setiap saat.

\section{Peran Camat}

Untuk melihat peran Camat dalam penertiban pasar liar, tentulah kita harus membahas dahulu yang dimaksud dengan peranan. Biddle dan Thomas penilain dan sanksi eksternal disebutnya disebutnya juga sebagai penilaian dan sanksi terbuka (overt), sedangkan yang internal disebutnya tertutup (covert). Mereka menyebutkan demikian karena penilaian dan sanksi didasarkan pada harapan tentang norma yang timbul dari orang lain yang di komunikasikan melalui perilaku yang terbuka (overt). Tanpa adanya pernyataan melalui perilaku yang terbuka, seseorang tidak dapat peroleh penilaian dan sanksi atas perilakunya (Sarwono, 2016).

Definisi peranan menurut Soekanto (2014), peranan adalah aspek dinamis dari kedudukan (status). Apabila seseorang melaksanakan hak dan kewajibannya sesuai 
dengan kedudukannya, maka dia menjalankan suatu peran. Dari definisi tersebut ditarik kesimpulan bahwa peran merupakan hak dan kewajiban dari suatu kedudukan seseorang. Peranan berfungsi sebagai tugas yang seharusnya dilakukan dan merupakan hal-hal yang sepantasnya diperoleh dari kepemilikan tugasnya, dan kedua hal tersebut harus dilakukan secara seimbang agar bisa dikatakan telah melaksanakan peranannya.

Camat memiliki peran penting dalam mengatur berbagai aktivitas yang dilakukan oleh masyarakat, termasuk juga pengaturan terhadap pasar agar keberadaan pasar tersebut tidak menimbulkan masalah bagi kelompok masyarakat lainnya (Hidayat, et al., 2020; Ridwan et.al., 2020; Sarumaha et al., 2017; Sitanggang, dan Suadi, 2014). Camat memiliki posisi sentral dalam menertibkan pasar liar mengingat camat sebagai perpanjangan tangan dari bupati cukup memahami kondisi masyarakat setempat, sehingga dapat diharapkan akan lebih didengarkan oleh masyarakat setempat.

\section{Harapan}

Harapan merupakan keinginan yang harus diwujudkan serta mendorong seseorang untuk melalui keadaan yang sulit. Semakin kuat harapan maka semakin tinggi dorongan positif untuk mencapai harapan. Demikian juga di Desa Lalang, harapan atas tercapainya tujuan menjadi factor kunci untuk membentuk dan mendorong perilaku, baik dengan menetapkan norma maupun dengan mewujudkan norma dalam bentuk perilaku. Harapan yang dimaksud terdiri dari harapan terhadap kondisi pasar tidak mengganggu kepentingan pengguna jalan raya, harapan terhadap peran pemerintah setempat yang diwakili oleh camat, serta harapan terhadap perilaku masyarakat setempat.

Harapan terhadap Kondisi Pasar Liar. Pasar liar di Desa Lalang yang mengambil posisi di pinggiran jalan atau bahkan ke badan jalan, telah menimbulkan masalah luar biasa seperti kemacetan yang cukup panjang pada jam sibuk jika tidak dikelola dengan baik. Disamping kemacetan, sering juga terdapat bau tak sedap sehingga sangat mengganggu bagi masyarakat umum.

Harapan utama terhadap kondisi pasar liar di Desa Lalang adalah agar tidak mengganggu kenyamanan pengguna jalan raya dan masyarakat lain yang berada di sekitarnya. Tokoh masyarakat berharap agar pasar liar tersebut benar-benar dapat ditertibkan karena masalah yang ditimbulkan lebih besar dibanding manfaatnya. Tetapi disisi lain dapat dikatakan bahwa kepentingan para pedagang yang menggunakan lokasi tersebut sebagai tempat berdagang juga jangan sampai dikorbankan (Jaffisa, et al., 2017; Sinaga, dan Yusnah 2015; Siregar, \& Indra, 2014).

Harapan terhadap Pemerintah. Pemerintah yang dalam hal ini adalah camat mempunyai peran penting dalam mengelola aktivitas masyarakat, terutama melakukan penertiban terhadap aktivitas masyarakat yang mengganggu kepentingan masyarakat lainnya. Oleh karena itu terdapat harapan besar agar pemerintah dapat mencari jalan terbaik untuk menertibkan pasar liar yang telah lama beroperasi di Desa Lalang.

Pemerintah diharapkan berperan aktif dalam mencari penyelesaian masalah terhadap pasar liar yang telah menimbulkan masalah di Desa Lalang. Pemerintah kecamatan yang sangat mengenal daerah tersebut diharapkan dapat mencari penyelesaian masalah tanpa mengorbankan para pedagang, walaupun hal tersebut sebenarnya tidak mudah untuk dilaksanakan. Pemerintah yang berwewenang memberikan izin juga tentu memiliki wewenang untuk menertibkan pasar liar yang tidak memiliki izin operasional.

Harapan terhadap Pelaku Pasar Liar. Harapan yang terbesar juga ditujukan kepada para pelaku pasar liar, khususnya para pedagang yang berjualan di pinggir jalan, dan juga kepada para pengurus pasar yang secara rutin menerima retribusi dari para pedagang. Harapannya adalah agar mereka tidak hanya mementingkan perolehan keuntungan semata, tetapi juga memikirkan bagaimana dampaknya terhadap masyarakat lainnya.

Harapan terhadap pedagang di pasar liar adalah agar mereka lebih memahami tentang pentingnya penggunaan jalan bagi pengguna lalu lintas, tidak justru memahaminya sebagai tempat berjualan. Harapan terhadap pemahaman masyarakat tentu sangat penting karena pada dasarnya kesadaran lebih bermanfaat dalam mengatasi masalah dibanding dengan himbauan atau bahkan paksaan. Namun demikian harapan tersebut tidak mudah diwujudkan mengingat para pedagang lebih perduli dengan sumber mata 
pencahariannya, dimana dengan menggunakan jalan raya sebagai tempat berdagang juga memudahkan pembeli untuk datang berbelanja.

\section{Norma}

Norma merupakan suatu peraturan yang merupakan petunjuk atau juga pedoman dalam perilaku yang benar dan pantas dalam melaksanakan perannya saat melakukan pekerjaan dan berinteraksi dengan orang lain. Norna ditetapkan pada dasarnya agar dapat mengubah atau membatasi atau mengarahkan perilaku individu untuk mencapai tujuan bersama yang diharapkan dapat diwujudkan di tengah masyarakat. Norma yang berhubungan dengan pengelolaan pasar adalah peraturan perizinan pembukaan pasar yang diterbitkan oleh pemerintah daerah, larangan penggunaan trotoar sebagai tempat berjualan, serta adanya control social yang terbentuk di tengah-tengah masyarakat.

Perizinan Pengelolaan Pasar. Setiap pasar yang terbentuk di Kabupaten Deli Serdang harus memiliki perizinan, yang diterbitkan oleh pemerintah setempat, yang dalam hal ini adalah Pemerintah Kabupaten Deli Serdang. Pengurusan izin tersebut harus dilakukan dengan melampirkan bebagai persyaratan yang ditetapkan, yang kemudian dilanjutkan dengan analisis kelayakan pembukaan pasar di tempat yang dimaksud.

Telah ada peraturan bahwa setiap pengelolaan pasar harus memiliki izin dari pemerintah setempat, dimana camat berperan memberikan rekomendasi. Tetapi sampai saat ini pasar liar di Desa Lalang tidak memiliki izin, walaupun telah lama diajukan oleh pengurus pasar kepada pemerintah, sehingga pasar tersebut tetap disebut sebagai pasar liar. Tidak terbitnya izin pengelolaan pasar tersebut tentu karena adanya permasalahan yang ditimbulkan sehubungan dengan tempat atau lokasi berdirinya pasar, sehingga pemerintah tidak berkenan memberikan izin operasional. Pemerintah tentu harus mempertimbangkan berbagai hal dalam memberikan perizinan, terutama dampaknya pengelolaan pasar tersebut terhadap kepentingan masyarakat umum.

Larangan Penggunaan Trotoar dan Badan Jalan.Terdapat aturan yang cukup jelas mengenai larangan penggunaan trotoar dan badan jalan sebagai tempat berjualan, dimana hal tersebut secara khusus diperuntukkan bagi lalu lintas kenderaan dan lalu lintas orang, sebagaimana diatur dalam UU Lalu Lintas dan Angkutan Jalan.

Penggunaan bahu jalan dan badan jalan untuk kepentingan lain telah dilarang, termasuk juga larangan untuk berjualan atau membuka pasar liar. Tetapi peraturan tersebut tidak ditegakkan secara tegas di Desa Lalang, walaupun pedagang telah sangat dekat hingga ke tengah jalan dalam membuka dagangannya. Penerbitan peraturan tanpa adanya upaya penegakan peraturan melalui penertiban tentu menyebabkan peraturan tersebut menjadi tidak berfungsi sama sekali.

Kontrol Sosial di Tengah Masyarakat. Norma yang cukup penting peranannya di tengah masyarakat dalam mengatur perilaku adalah control social, yang dilakukan oleh anggota masyarakat terhadap anggota masyarakat lainnya. Kontrol sosial telah lama diakui dapat membentuk dan mengarahkan perilaku masyarakat untuk tidak menyimpang.

Kontrol sosial juga telah menjadi norma yang terbentuk di pasar liar Desa Lalang, tetapi hal tersebut tidak mampu mengubah perilaku pedagang agar lebih menghindari penggunaan badan jalan untuk berjualan. Pedagang bahkan sering dimaki oleh para pengguna jalan raya karena merasa jalannya terganggu atau bahkan mungkin hampir menimbulkan kecelakaan lalu lintas. Tetapi dalam hal ini para pedagang telah kebal dengan makian dari para pengguna jalan dan juga tidak mengindahkannya, dan pedagang telah mengganggapnya sebagai risiko yang harus ditanggung dari berjualan di pasar liar yang menggunakan badan jalan.

\section{Wujud Perilaku}

Wujud perilaku merupakan sikap dan tindakan yang sangat berpengaruh terhadap upaya pencapaian tujuan yang diharapkan. Wujud perilaku dengan demikian merupakan hal-hal yang dilakukan oleh individu anggota organisasi, serta hasil-hasil yang diperoleh dari perilaku atau tindakan yang dilakukan oleh individu organisasi yang bersangkutan. Dalam peran camat penertiban pasar liar, camat telah melakukan berbagai upaya sebagai bentuk perannya, sesuai dengan wewenang yang ada padanya. Berbagai hal yang dilakukan oleh camat adalah melakukan upaya preventif dan persuatif. 
Upaya Preventif. Upaya preventif merupakan upaya yang dilakukan sebagai tindakan pencegahan agar pelanggaran tidak terjadi. Dalam hal ini camat harus berperan melakukan berbagai upaya untuk mencegah agar pedagang di pasar liar Desa lalang tidak menggunakan badan jalan sebagai tempat berjualan, seperti melakukan sosialisasi peraturan larang berjualan di pinggir jalan, menyadarkan masyarakat agar memahami pentingnya memahami peraturan yang ditetapkan.

Pihak Kecamatan Sunggal sudah membuat sosialisasi kepada masyarakat mengenai larangan penggunaan badan jalan sebagai tempat pembukaan pasar liar. Pentingnya sosialisasi karena masyarakat perlu paham benar akan larangan tersebut yang dapat menggangu ketertiban umum. Masyarakat ingin agar dapat berjualan untuk memenuhi kebutuhan keluarganya, tetapi tindakan berjualan di badan jalan dapat mengganggu masyarakat yang lain. Memang tidak mudah bagi masyarakat untuk paham dengan tindakan mereka berjualan di badan jalan, dengan adanya sosialisasi yang dilakukan maka diharapkan para pedagang lebih mudah paham dan patuh dengan peraturan yang berlaku.

Camat telah memberikan pengarahan bahwa fungsi badan jalan bagi kepentingan publik, dimana hal tersebut juga telah di atur dalam berbagai peraturan hukum. Hal ini diharapkan dapat menyadarkan masyarakat untuk tidak melanggar peraturan larangan berjualan atau membuka pasar liar di badan jalan, serta menghargai kepentingan orang lain atas penggunaan pinggir jalan.

Upaya Persuasif. Upaya persuasif merupakan upaya yang dilakukan dengan pendekatan lunak bagi pedagang yang telah menggunakan badan jalan sebagai tempat berjualan di pasar liar Desa Lalang. Peran camat dalam hal ini adalah melakukan komunikasi untuk meminta pedagang membongkar sendiri tempat berjualannya tanpa paksaan dari petugas.

Komunikasi antara petugas kecamatan dengan pedagang dan pengurus pasar liar Desa Lalang dilakukan sebagai upaya negosiasi dan dilakukan secara bertahap untuk mencari penyelesaian, sehingga diharapkan dapat menghindari aksi adu mulut, apalagi saling jotos dan kejar-kejaran antara petugas dan pedagang sebagaimana yang selama ini terjadi di berbagai tempat. Penyelesaian secara damai dengan meminta kerelaan pengelola pasar liar mengosongkan badan jalan tentu akan lebih baik, walaupun upaya tersebut tidak selalu berhasil.

\section{Evaluasi dan Sanksi}

Evaluasi merupakan langkah untuk melakukan penilaian terhadap tingkat keberhasilan organisasi dalam mencapai tujuan, serta mencari penyelesaian terhadap penyebab kurang berhasilnya pencapaian tujuan. Evaluasi juga harus disertai dengan adanya sanksi jika ditemukan adanya pelanggaran yang menyebabkan kurang berhasilnya pencapaian tujuan, sebagaimana akan diuraikan berikut ini.

Evaluasi terhadap Kondisi Pasar Liar. Evaluasi terhadap pencapaian tujuan harus dilakukan secara objektif, yaitu berdasarkan fakta-fakta yang ditemukan. Dengan demikian penilaian terhadap hasil yang dicapai akan menggambarkan kondisi yang sesungguhnya.

Kondisi pasar liar di desa lalang tidak mengalami perubahan walaupun camat telah melakukan berbagai upaya untuk melakukan penertiban. Camat telah dianggap gagal melakukan penertiban terhadap pasar liar tersebut, padahal telah banyak camat yang berusaha menanganinya. Hal ini tentu tentu tidak lepas dari adanya berbagai kendala, serta tidak adanya keperdulian masyarakat terhadap kepentingan orang lain.

Sanksi terhadap Pengurus dan Pedagang di Pasar Liar. Sanksi merupakan bagian penting dari penegakan aturan yang berlaku. Tanpa sanksi yang jelas dan ditegakkan dengan tegas, maka dipastikan aturan juga akan kurang dipatuhi.

Tidak ada sanksi yang jelas yang diberikan kepada para pedagang dan pengurus pasar liar di Desa Lalang. Hal ini juga disebabkan keberadaan pasar liar tersebut juga atas sepengetahuan kepala desa, dimana kepala desa juga turut serta mengutip retribusi dari para pedagang sebagai sumber pendapatan asli daerah. Terdapat banyak pihak yang berkepentingan dengan keberadaan pasar tersebut sehingga tindakan penertiban menjadi sulit untuk dilakukan. Upaya pengaturan lebih baik dibanding dengan upaya penutupan secara total terhadap pasar liar. 


\section{SIMPULAN}

Camat Sunggal belum sepenuhnya mampu berperan sesuai dengan harapan untuk melakukan penertiban terhadap pasar liar di Desa Lalang. Camat telah melakukan berbagai upaya yang meliputi upaya preventif dan upaya persuasif untuk menutup pasar liar tersebut, tetapi segala upaya yang dilakukan oleh camat tidak ditanggapi atau tidak diindahkan oleh pengelola dan pengurus pasar liar. Hal ini menyebabkan sampai saat ini pasar liar di Desa Lalang tetap menimbulkan kemacetan panjang dan mengganggu arus lalu lintas.

\section{DAFTAR PUSTAKA}

Blair, J.P. (2015). Local Economic Development, Analysis and Practice. California, USA: Sage Publications Inc.

Dahlia, D., Harahap, D., \& Lubis, Y. (2020). Analisis Kualitas Pelayanan Di Kantor Kelurahan Pasar Baru Kecamatan Sei Tualang Raso Kota Tanjungbalai. Strukturasi: Jurnal Ilmiah Magister Administrasi Publik, 2(2), 107-115. doi:https://doi.org/10.31289/strukturasi.v2 i2.51

Dari, W., \& Adlin, A. (2021). Beleidsregel Dinas Perdagangan dan Perindustrian dalam Mengoptimalkan Pasar Rakyat Tualang Tahun 2018. Journal of Education, Humaniora and Social Sciences (JEHSS), 4(2), 923-930.

doi:https://doi.org/10.34007/jehss.v4i2.771

Dwika, S., Kismartini, K., \& Dwimawanti, I. (2020). Implementasi Kebijakan Retribusi Pelayanan Pasar di Pasar Adiwerna Kabupaten Tegal. Journal of Education, Humaniora and Social Sciences (JEHSS), 2(3), 561-572. doi:https://doi.org/10.34007/jehss.v2i3.112

Ginanjar, N.J. (2012). Masalah Ekonomi Mikro. Jakarta: Acro

Heri, R., Nasution, M., \& Isnaini, I. (2020). Analisis Pelaksanaan Fungsi Pengawasan Inspektorat Daerah Terhadap Dana Desa Pasar Lapan Kecamatan Air Putih Kabupaten Batubara. Strukturasi: Jurnal Ilmiah Magister Administrasi Publik, 2(2), 190-203. doi:https://doi.org/10.31289/strukturasi.v2 i2.59

Hidayat, R., Badaruddin, B., Warjio, W., \& Isnaini, I. (2020). Implementasi Peraturan Bupati Aceh Tamiang Nomor 14 Tahun 2016 Tentang Pelimpahan Sebagian Kewenangan Bupati Kepada Camat. Strukturasi: Jurnal Ilmiah Magister Administrasi Publik, 2(1), 14-25.

Jaffisa, T., Abdul K., Dumasari H., (2017), Peranan Camat dalam Pengawasan Disiplin Pegawai Negeri Sipil di Kantor Kecamatan, Jurnal Administrasi Publik : Public Administration
Journal : Public Admnistration Journal, 7 (1): 94-93

Kotler, P and Amstrong, G. (2001). Prinsip-prinsip Pemasaran. Jakarta: Penerbit PT. Erlangga.

Moleong, L J. (2010). Metodologi Penelitian Kualitatif, Bandung: Rosda Karya.

Pakpahan, E.F., Sianipar, B.D. Angkasa, J., Sianturi, V.R., Hulu, S.R. (2019). Peran Pemerintah dalam Mitigasi Kejahatan Pasar Indonesia. Journal of Education, Humaniora, and Social Sciences (JEHSS), 2 (1): 104-118

Ridwan, R., Kusmanto, H., Warjio, W., \& Kadir, A. (2020). Efektivitas Kinerja Satuan Polisi Pamong Praja dalam Penertiban Pedagang Kaki Lima di Pasar Peureulak Gampong Keude Kabupaten Aceh Timur. Strukturasi: Jurnal Ilmiah Magister Administrasi Publik, 2(1), 39-47

Ridwan, R., Kusmanto, H., Warjio, W., \& Kadir, A. (2020). Efektivitas Kinerja Satuan Polisi Pamong Praja dalam Penertiban Pedagang Kaki Lima di Pasar Peureulak Gampong Keude Kabupaten Aceh Timur. Strukturasi: Jurnal Ilmiah Magister Administrasi Publik, 2(1), 39-47

Sarimah, Nasution, I. \& Muhammad A.H., (2016), Peran Dinas Pasar Kabupaten Deli Serdang dalam Meningkatkan Kebersihan Pasar Galang, JPPUMA: Jurnal Ilmu Pemerintahan dan Sosial Politik UMA (Journal of Governance and Political UMA), 4 (2): 118131.

Sarimah, Nasution, I. \& Muhammad A.H., (2016), Peran Dinas Pasar Kabupaten Deli Serdang dalam Meningkatkan Kebersihan Pasar Galang, JPPUMA: Jurnal Ilmu Pemerintahan dan Sosial Politik UMA (Journal of Governance and Political UMA), 4 (2): 118131.

Sarumaha, W.Y. Dewi, R. Batubara, B.M. (2017). Peran Camat dalam Mengawasi Kinerja Pegawai Di Kantor Camat Medan Denai Kota Medan. PERSPEKTIF, 6 (1): 25-36

Sarwono, S, (2011), Psikologi Remaja, Jakarta: Rajawali Pers.

Sinaga, M.C.D.M. dan Yusnah M., (2015). Pelaksanaan PP RI No.19/2008 Sebagai Acuan Kinerja Camat pada Aspek Pemerintahan dan Pendidikan, JPPUMA: Jurnal Ilmu Pemerintahan dan Sosial Politik UMA (Journal of Governance and Political UMA), 3 (1): 36-48.

Siregar, M., \& Indra M., (2014). Usaha-Usaha Camat Dalam Rangka Pembinaan Masyarakat Untuk Meningkatkan Pembangunan di Desa Securai Selatan, Jurnal Administrasi Publik Universitas Medan Area, 2 (2): 122-128

Sitanggang, M.D., dan Suadi H., (2014). Persepsi Masyarakat Terhadap Kinerja Camat Dalam 
Muhammad Nurdin, Adam \& Budi Hartono, Peran Camat dalam Penertiban PasarLiar di Desa Lalang

Meningkatkan Mutu Pendidikan, JPPUMA: Jurnal Ilmu Pemerintahan dan Sosial Politik UMA (Journal of Governance and Political UMA), 2 (1): 58-77

Soekanto, S. (2014). Sosiologi Suatu Pengantar, Jakarta: Raja Grafindo Persada.

Suharyanto, A., Kadir, A., \& Kusmanto, H. (2020), Medan City Government Regulation in Managing Traditional Markets and Modern Stores. Proceedings of the 5th NA
International Conference on Industrial Engineering and Operations Management Detroit, Michigan, USA, August 10 - 14, 2020. Suharyanto, A., Kadir, A., Kusmanto, H., Isnaini, \& Lubis, A.A., (2020), Medan City Government Regulation in Managing Traditional Markets and Modern Stores, Proceedings of the 5th NA International Conference on Industrial Engineering and Operations Management Detroit, Michigan, USA, August 10 - 14, 2020 